\title{
Introduction: Tales of Seductive Feminisms
}

\author{
Katherine Binhammer
}

Seduction-feminist or otherwise-is always a narrative. It requires a passage of time, a beginning, middle and end, and, somewhere along the way, there is a climactic moment in which a loss of innocence is traded for a gain of pleasure. At this narrative crisis, knowledge emerges: the seduced knows now what she did not know then. After all, Eve was seduced for a reason. But the apple, regrettably, gave seduction a bad rap and tales of seduction since have included plots overflowing with snares, tricks, and betrayals - the stuff not normally associated with feminist narratives.

Is it possible to rewrite the snares of seduction as sexual and political invitations? To see the revelation of unknown knowledge not correspondent with the seducer's betrayal but with political desire and sexual pleasure? The sexual erotics of politics has a complicated history within feminism. At times a seduction by feminism-the playful falling into, and celebration of, the erotics of feminist politics-has been staged as an uncritical and naive enticement, a betrayal of equitable sisterhood through the corruption of power. We should not allow ourselves to be seduced, this position exhorts, but must come to feminism with eyes open and mouths closed. At other times, denying the pleasure of the seduction, refusing the eroticization of politics, leads to accusations of repression and censorship. How can we tell tales of seductive feminisms that narrate both pleasure and a critical politics? Most of us have our own tales of seductive feminism-how we came to call ourselves feminists, how we entered the knowledge of political awareness, and how it gave us pleasure. And, for most of us, these tales don't involve tricks, or, at least, not tricks of the bad kind. These tales, no doubt, change generationally as each moment in history offers to us a range of possible narratives. Some are more compelling than others, some insist that sex and politics use the same positions, and others reject the possibility that the narratives of gender and sexuality could coincide.

I want to tell you a few tales from this collection of seductive feminisms, and, along the way, seduce you into a narrative of recent feminist history. 


\section{A Tale of Seductive Feminism: Around 1971}

Gender is a socially imposed division of the sexes. It is a product of the social relations of sexuality.

—Gayle Rubin, "Traffic in Women" (1975)

It is 1971 and the feminist movement hits the campus where Jane Gallop is a young college student. She comes alive and gets seduced by the excitement of its explosive ideas. She reads books, attends meetings, and feels the desire of and for women swell up in her mind and body. She not only becomes a better student because ideas finally matter, but "[t]hanks to feminism," she writes, " my sex life improved" (4). "In January 1971," she continues, "I read de Beauvoir's Second Sex, learned that women could masturbate, and had my first orgasm" (4). In 1971, when Gallop credits feminism with bringing her to her first sexual climax, women were naming and then rising up against the sex/gender system which used their sexuality to oppress them; to Gallop and others, it seemed like the journey to feminism went hand and hand with a sexual awakening. Thus, in her primal scene of feminist seduction, the political and sexual are interchangeable:

My initial and formative experience of feminism was this entry into a milieu bubbling indiscriminately with ideas and lusts. Feminism turned me on, figuratively and literally: my body and my mind began firing, pulsing with energy, an energy that did not distinguish between mind and body. Feminism made me feel sexy and smart; feminism felt smart and very sexy. When I call myself a feminist, as I have for twenty-five years, I necessarily refer to that milieu where knowledge and sex bubble together, to that possible community, to that possibility for women. (6)

More than twenty years after the political and sexual arousal of her feminism, Gallop is accused by two female graduate students of sexual harassment, and, under the University of Wisconsin's sexual harassment policy, she is later reprimanded for having 'consensual amorous relations' with a student. The case becomes a sensation, both because Gallop is a feminist, academic 'star,' and because her accusers are women; thus, a sexual harassment policy designed to protect women from the sexual oppression of men is used by women against another woman. Gallop publishes Feminist Accused of Sexual Harassment in 1997. Her defence against sexual harassment is that feminism should be sexy, and its mandate should include helping women find sexual pleasure. She recounts her primal 
scene of feminist seduction repeatedly to underscore her defence, and the text creates a nostalgia for a time when sex and politics went hand in hand within the feminist movement, when her gender and sexuality seamlessly molded into an active, desiring, feminist, intellectual subject. But in 1992, her students respond differently to her attempts at feminist seduction; they feel disempowered and do not get turned on by the figurative and literal mixing of bodies and minds, the flamboyant fusion of a politics of gender with the pleasure of sexuality. They feel betrayed.

\section{A Tale of Feminist Seduction: Holly Hughes Goes to Manhattan}

I want to challenge the assumption that feminism is or should be the privileged site of a theory of sexuality. Feminism is the theory of gender oppression. To automatically assume that this makes it the theory of sexual oppression is to fail to distinguish between gender, on the one hand, and erotic desire, on the other.

—Gayle Rubin, "Thinking Sex" (1984)

Around 1980, Holly Hughes, soon to become an in/famous performance artist, arrives on the feminist scene in New York. She's a thirsty queer from the Midwest who wants food for her art, for her budding feminism, and for her lesbian desire. Her first feminist seduction isn't as successful as Jane's. For Holly, the encounter with feminism is a big turn off:

I assumed that wanting to have sex with women meant I was a lesbian, so I went looking for other lesbians who I hoped would show me the ropes, so to speak. I did find dykes who were only too willing to set me straight. What made somebody a lesbian, I was told, wasn't wanting to have sex with women; it was wanting to get away from men. In fact, if you admitted you wanted to have sex with women, you would be accused of being just like a man; it was the very worst thing you could do. Apparently, sex was something lesbians used to do before they got politics and opened food co-ops. (13)

Hughes escapes the feminist co-ops and runs away to the East Village where she finds the scene of her lesbian seduction. It is staged within the experimental theatrical space of WOW café and a group of sexy lesbianthespians star in both her sexual and theatrical fantasies. Defined against a desexed feminism, the women who come to WOW are assumed to be looking for two things: "pussy and a place to perform" (15). They begin making art and love in a space where gender is both a question for feminism and something to be fucked. 
In 1990, two years before Gallop is accused of sexual harassment, Hughes finds herself at the centre of a controversy. The then director of the National Endowment for the Humanities in the United States overturns the decision of peer reviewers and denies funding to four performance artists, one of whom is Holly Hughes. ${ }^{1}$ The NEA stamps Hughes' work 'obscene' because it is sexually explicit and lesbian, and this stamp of disapproval galvanizes Hughes and a larger queer activist community to fight against censorship-feminist or otherwise. Hughes feels betrayed by pro-censorship feminists.

\section{A Feminist Tale of Seduction: The Daughter's Not a Love Story}

I will only say that I never claimed that sexuality and gender were always unconnected, only that they are not identical. Moreover, their relationships are situational, not universal, and must be determined in particular situations.

—Gayle Rubin, "Sexual Traffic. Interview with Judith Butler" (1994)

On December 6, 1989 columnist Naomi Klein, daughter of Bonnie Sherr Klein (writer and director of the anti-pornography documentary Not a Love Story) becomes a feminist. Her seduction is violent. She is a nineteen year old University of Toronto student sitting in a friend's dorm room watching the news coverage of the Montreal Massacre and she is forced into her feminist epiphany by the brutal act of violence. No matter how fast she runs from her mother's politics or how stridently she declares her individual, sexual, and intellectual freedom against what she perceives as feminist dogma, she realizes on December 6, 1989 that when she walks into a classroom the next day, she is a woman no different from the women Mark Lepine murdered. This realization leads her to take up the feminist cause on campus with a vengeance. Seeing male violence everywhere, she participates in date-rape awareness campaigns, repeats the slogan "one in four women have been raped," and writes an essay for a women's studies class that claims the only nonviolent heterosexual sex occurs if the man isn't on top (116-117).

When Holly Hughes is experiencing the first flush of sexual theatrical creativity in early 1980s New York, Naomi Klein is a child in Montreal having to watch a private family screening of Not a Love Story and hating it. She vows never to watch it again and equates her mother's feminist politics with coercion, lack of choice, and barring her from a feminine sexuality of tight jeans and bleach blonde hair. Ten years later, the Montreal Massacre forces her to change her mind and she begins to understand the 
links between sexism, sex and violence. But the campus world she emerges into with this new found knowledge is not the same campus of Gallop's primal scene nor does she participate in the same feminist antiviolence campaign of her mother's era. And while she tries on the persona of the angry feminist campaigning against sexual assault, the persona just doesn't fit. It doesn't ring true. Collective feminist consciousness and action isn't what turns her on. On her campus, not all the men are violent and not all the women are victims. Some women are powerful and some men are weak. She finds herself reading "Paglia-inspired feminist-bashers" and while she takes apart their arguments, part of her "is also attracted to these women who brag that they (unlike those weak and prudish feminists) aren't afraid of the dark, can handle any sexist pig who pats their ass, don't need any special privileges to get jobs, and even enjoy a little porn in their spare time" (118). "Feminism," she concludes, "is about finding your strength, and I know I'm that strong too" (118). She still thinks of herself as a feminist but it means something different for her. It's fluid and situational, it's individual and non-sexual: "Desire so rarely obeys rhetoric-no matter how well reasoned. Theorizing about the politics and morality of sex is dangerous territory" (117), and so she leaves sex out of it.

\section{A Seductive Tale of Feminism}

Three tales. Three moments in the history of three decades of feminist politics and culture. There is a seductive tale to be told which makes sense of this triad and it goes something like this.

In the beginning (the 1970s), feminism theorized sexuality and gender as co-extensive in order to articulate an analysis of sexual (understood as gender) oppression; then, in the 1980s, the lesbian and gay movement argued that sexuality and gender were not the same thing in order to articulate an analysis of sexual (understood as sexuality) oppression. Today, as feminists and lesbians find their way out of the sex wars, the costs of making definitive proclamations about gender and sexuality seem too high and history appears too fragmented to tell only one tale. In place of firm knowledge, we have particular, situational, and specific knowledges. From Gallop's sexual and political seduction to Hughes' experience of the disjunction between feminism and her sexuality to Klein's furtive and abortive attempt at reclaiming her mother's feminism, these three tales stand in as representative moments in this narrative.

But how true is this story? What knowledge can be gained from recounting it? Will we be betrayed by the seductiveness of the progression it suggests? 
This seductive tale circulates in contemporary feminist and lesbian culture. Kathleen Martindale, for example, begins Un/Popular Culture: Lesbian Writing after the Sex Wars by sketching a similar tripartite narrative in her theorizing of the category 'lesbian': first, lesbian-feminism (represented by Adrienne Rich's landmark essay "Compulsory Heterosexuality and Lesbian Existence") defined lesbian sexuality as central to feminism; then, the 1982 outbreak of the sex wars severed lesbianism and feminism; and, lastly, the lesbian postmodern has now emerged as the "sexy new avantgarde at a time too 'post' to believe in the possibility or usefulness of either lesbianism or feminism" (2). But Martindale, herself, queries this easy narrative because, while "the story in its broad outlines is correct, what is becoming the received version fails to do justice to the theoretical complexity and the contradictions of lesbian-feminism" (1). Similarly, many of the contributors to Cross Purposes: Lesbians, Feminists, and the Limits of Alliance tell the tale only to interrogate it. Bonnie Zimmerman marks the historical shifts in second-wave feminism only to reject the trajectory as a personal narrative; she adamantly claims that "lesbianism and feminism have never been separate or unconnected in my life" (158). Sue-Ellen Case revisits her article "Toward a Butch-Femme Aesthetic," - what she calls her "butch seduction/bar fight with feminism" (205)-in order to point out that she never rejected feminism to side with the lesbian camp. Her intention was to "seduce feminism," and, from her classic "butch bottom" position, to throw a "tantrum" and force feminism to become more inclusive (205). She questions a contemporary revisionist history around which queer emerges out of the dated, staid, boring, "lesbian feminist ashes" (210) and she wants to engender a " butch-feminist retro-future" which simultaneously tells and untells the seductive tale. Her retro-future tale learns from the past in order to progress and is not blind to past betrayals, but it also understands when this past is a wishful projection and her tale playfully acknowledges the seduction of feminist knowledge. A butchfeminist retro-future, Case writes, "seeks an agenda that might animate both a modernist project of doing something historical about the future and the ironic, postmodern sense of retro that, by the conjunction, still performs a critique of the categories of historical past and future" (218). I want these tales of seductive feminism and my seductive tale of feminism to be read within the context of a butch-feminist retro-future. The three stories I have sketched provide important symbolic markers of moments, issues, and knowledges in recent feminist history. But these moments are always already more than themselves. We invoke them to make meaning of our feminist past in order to chart a course for the future, and we hope 
our future path will unpack the theoretical and political quagmire of gender and sexuality. Yet, the tales always leave something out; they always involve a forgetting, a partial knowledge. Blinded by the pleasure of narrative and desire, we awake from our feminist seductions not betrayed but incomplete. And what comes after the fall requires a constant teasing, a flirtation with feminist knowledge that engages the uncritical critically.

\section{Notes}

I would like to thank the members of the Tessera collective, especially Lauren Gillingham and Julie Murray, for helpful suggestions on this introduction.

${ }^{1}$ Karen Finley, John Fleck and Tim Miller are the other three. Miller and Fleck deal with gay male sexuality in their art and Finley's art is loudly feminist.

\section{Works Cited}

Case, Sue-Ellen. "Toward a Butch-Feminist Retro-Future" in Cross Purposes: Lesbians, Feminists, and the Limits of Alliance. Ed. Dana Heller. Bloomington: Indiana UP, 1997. 205-220.

Gallop, Jane. Feminist Accused of Sexual Harassment. Durham: Duke UP, 1997.

Heller, Dana, ed. Cross Purposes: Lesbians, Feminists, and the Limits of Alliance. Bloomington: Indiana UP, 1997.

Hughes, Holly. Clit Notes. New York: Grove Press, 1996.

Klein, Naomi. "Coming Unclicked" in Click: Becoming Feminists. Ed. Lynn Crosbie. Toronto: Macfarlane Walter \& Ross, 1997. 109-118.

Martindale, Kathleen. Un/Popular Culture: Lesbian Writing After the Sex Wars. Albany: SUNY Press, 1997.

Rubin, Gayle. "The Traffic in Women: Notes on the 'Political Economy' of Sex" in Toward an Anthropology of Women. Ed. Rayna R. Reiter. New York \& London: Monthly Review Press, 1975.

---. "Thinking Sex: Notes for a Radical Theory of the Politics of Sexuality" in Pleasure and Danger: Exploring Female Sexuality. Ed. Carole S. Vance. Boston \& London: Routledge, 1984.

Rubin, Gayle with Judith Butler. "Sexual Traffic. Interview" in Feminism Meets Queer Theory. Eds. Elizabeth Weed \& Naomi Schor. Bloomington: Indiana UP, 1997.

Zimmerman, Bonnie. "Confessions' of a Lesbian Feminist" in Cross Purposes: Lesbians, Feminists, and the Limits of Alliance. Ed. Dana Heller. Bloomington: Indiana UP, 1997. 157-168. 